\title{
Assessing the Thermal Performance of Negeri Sembilan Traditional Malay House towards Sustainable Practice
}

\author{
Nik Siti Fatimah Nik Hassin ${ }^{1}$, Alamah Misni² \\ ${ }^{1}$ Institute of Postgraduate Studies, Faculty of Architecture, Planning and Surveying, \\ Universiti Teknologi MARA, 40450 Shah Alam Selangor, Malaysia \\ ${ }^{2}$ Faculty of Architecture, Planning and Surveying, \\ Universiti Teknologi MARA, 42300 Puncak Alam, Selangor, Malaysia \\ nsfatimahhassin@gmail.com, alamahmisni@gmail.com \\ Tel: $+6019-4303134$
}

\begin{abstract}
Traditional Malay house has characteristics of the passive thermal design that naturally practices climatic design strategies. Currently, Urban Heat Island (UHI), causing an increase in energy consumption for cooling purposes, especially in the residential sectors. Consequently, modern building construction has a poor passive thermal design. This study aims to assess the thermal performance of Negeri Sembilan traditional Malay house towards sustainable practice in the tropical environment. The main finding shows that house openings allow natural cross-ventilation, while less strategic house orientation towards climate factors and lightweight materials used contributes to the uncomfortable of the interior spaces reaches as much as $35^{\circ} \mathrm{C}$ during the peak time of the day. This study highlights ideas and knowledge in improving the construction technology for modern architecture to produce an effective indoor thermal performance in a tropical environment.
\end{abstract}

Keywords: Malay House; Traditional Architecture; Thermal Performance; Tropical; Environment

eISSN: 2398-4287 @ 2019. The Authors. Published for AMER ABRA cE-Bs by e-International Publishing House, Ltd., UK. This is an open access article under the CC BYNC-ND license (http://creativecommons.org/licenses/by-nc-nd/4.0). Peer-review under responsibility of AMER (Association of Malaysian Environment-Behaviour Researchers), ABRA (Association of Behavioural Researchers on Asians) and cE-Bs (Centre for Environment-Behaviour Studies), Faculty of Architecture, Planning \& Surveying, Universiti Teknologi MARA, Malaysia.

DOI: https://doi.org/10.21834/e-bpj.v4i12.1914

\subsection{Introduction}

The traditional architecture employs relatively sophisticated architectural processes ideally suited to the tropical environment. The tropical climate is often one of a warm and humid environment. Malaysia is one of the countries located within the equatorial zone. Throughout the year, the climate temperature is stable, ranging between 28 and $32^{\circ} \mathrm{C}$ during the day time. According to Naseer (2013), traditional architecture has a high value in terms of construction methods, which it has a common characteristic of passive thermal design that fit with the local environmental condition. Traditional Malay house is one of the best examples of traditional architecture in Malaysia that practice the climatic design strategies (Toe et al., 2013). This remarkable architecture has emphasized the climatic design of construction and design in giving the occupants the optimal thermal comfort. Previous studies have highlighted that every detail in the creation of traditional Malay house i.e., adapts to the environment which responsively to the surrounding physical and climate, and use of lightweight material (low thermal conductivity materials) help to create excellent thermal performance in the house.

However, the traditional Malay house was experiencing numerous changes and confronted with consistent dangers to its proceeded presence (Cockrem, 2003). Sahabuddin (2016) stressed that when observed the current scenario of housing projects throughout Malaysia, it is practically none concept of housing that can match the 'ancient science' concept of traditional Malay house. Furthermore, rapid urban development has driven urban sprawl due to the growth of the population (Chung et al., 2018). It has created Urban Heat Island (UHI) in the city (Ramakreshnan et al., 2018). It has caused energy utilization, increasing for cooling purposes in the residential

eISSN: 2398-4287 @ 2019. The Authors. Published for AMER ABRA cE-Bs by e-International Publishing House, Ltd., UK. This is an open access article under the CC BYNC-ND license (http://creativecommons.org/licenses/by-nc-nd/4.0). Peer-review under responsibility of AMER (Association of Malaysian Environment-Behaviour Researchers), ABRA (Association of Behavioural Researchers on Asians) and cE-Bs (Centre for Environment-Behaviour Studies), Faculty of Architecture, Planning \& Surveying, Universiti Teknologi MARA, Malaysia. DOI: https://doi.org/10.21834/e-bpj.v4i12.1914 
sector (Misni, 2017; Lundgren et al., 2013; Cartalis et al., 2001). Zin et al. (2012) have described that modern building construction is poor in passive thermal design, while Toe et al. (2013) found that the use of passive design to achieve thermal comfort in buildings is referring to the passive design system in traditional Malay houses. It is because it has better thermal performance compared to modern homes. Thus, the primary purpose of this study is to assess the thermal performance of Negeri Sembilan traditional Malay house in a tropical environment towards sustainable practice.

\subsection{Literature Review}

To achieve the optimal climatic control, the Malays designed and built the house by taking these points much into account. As a result, the Malay house construction appropriately to suit specifically to the vagaries of the tropical climate of Malaysia. It is appreciably suited to the local environment than the modern Western-style brick house (Yuan, 1988). Based on previous studies by Toe et al. (2013), there are four primary thermal qualities features of a traditional Malay house. They are traditional Malay village and compound, raised floor, walls and openings, and double-slope roof.

\subsection{Traditional Malay Village and Compound}

The Malay houses are arranged sparsely and randomly in the linear village area settlement. The house is detached from other dwellings and scattered units with ample exterior spaces. This unplanned arrangement indirectly helps to lessen the prevailing winds where settlements along coastal areas experience higher wind speed than inland regions (Kubota et al., 2012; Sahabuddin, 2012). Besides, it is also ensuring that wind velocity in the houses in the latter path of the wind will not substantially reduce (Kamal et al., 2004). The Malays traditionally selected the house sites by observation, sunlight orientation, and religious rituals. As for religious reasons, traditional Malay houses are often oriented to face Kaaba (Mecca) $\left(292.5^{\circ}\right.$, east-west direction), which indirectly minimizes the area of exposed walls to direct solar radiation during the day (Yuan, 1988). Crop-bearing trees such as coconut trees and high-branched fruity trees are commonly planting in Malay house compounds. Besides, it also does not block the passage of winds at the house level. The open space compounds of a traditional Malay kampong can encourage social interaction within neighborhoods (Sahabuddin, 2012; Yuan, 1988).

\subsection{Raised Floor}

In providing sufficient ventilation and safety, the house is constructed and built on stilts. This idea and approach, in many ways, have various benefits for the peoples living in the house. The benefits can be from a thermal, functional, and safety point of view (Sahabuddin et al., 2015). The raised floor, which is built higher than the ground, can catch winds of higher velocity (Yuan, 1987), and the floor joist, which provides small gaps among the plank, can convey the air to the interior (Hosseini et al., 2014). Hanafi (1994) deduced that the raised floor is one of the solutions to the moist ground, which requires more sunlight to dry. Besides, it is allowing cross-ventilating breezes beneath the house while mitigating the effects of the occasional flood (Amad et al., 2007). Moreover, it is also to ensure safety from possible attacks by wild animals in their surroundings.

\subsection{Walls and Openings}

In conjunction to maximize indoor ventilation, the house designed having plenty of full-height operable windows and doors at body level (Kubota et al., 2012; Sahabuddin et al., 2015). The body level is the most vital area for indoor ventilation (Kamal et al., 2004). The study by Hosseini et al. (2014) claims the windows are often designed in large openings with upper ventilation grilles and minimal partitions inside the house to create a sense of openness for the functional spaces. Besides, Kamal et al. (2004) also claim that elongated open plans of the house in which minimal interior partitions allow easy passage of air and proper cross ventilation. Talib et al. (2012) and Hosseini et al. (2014) has stated in their study that windows or openings with upper ventilation grilles help in allowing natural wind inside the house, which helps create the cross-air ventilation. However, an analysis by Hassan et al. (2010) revealed that maximum openings on the walls create high air intakes outside the house to give the poor performance of the stack effect.

\subsection{Double-Slope Roof Walls and Openings}

Roof space in a traditional Malay house is adequately ventilated by the provision of ventilation joints and panels in the roof construction (Kamal et al., 2004). The slope gable roof pitched allowed the air-ventilated through space below (attic space), which cools the house effectively. Besides, it is to perforate out the warm air and keep in a cold condition (Hosseini et al., 2014). Yuan (1988) claims that the attap roof used in Malay houses is an excellent thermal insulator. This material does not retain heat and cools immediately. Besides, gable ends (Tebar Layar) is another climatic responsive design of a double-slope roof. It has various motive designs and as part of the aesthetic element to the ceiling. This component also has ventilation panels that allow proper ventilation into the roof space and cool the interior of the house. The gable ends with ventilation in traditional Malay houses and can reach up to about 5 to 9 meters high (Sahabuddin, 2016). Also, the broad roof eaves cover with a lightweight and excellent thermal insulator made from the fronds of the local palm trees, which holds little heat during the day and cools down at night.

\subsection{Methodology}

A field measurement was conducted in one of the traditional Malay houses in Negeri Sembilan, which is located at Kg. Cheriau, Kuala Pilah, Negeri Sembilan. Kuala Pilah is located $37.9 \mathrm{~km}$ to the east of Seremban. The house form of the house is the long roof, and the typology is Rumah Bumbung Panjang Berserambi dua and Beranjung. The house has the typical Malaysian rural village setting with 
carefully planting vegetation and lawn compound area. The total area of the house is $153.8 \mathrm{~m} 2$. There are four spatial divisions in this Malay house. They are anjung, serambi, rumah ibu, and a kitchen (Figure 1(a)). It has timber structure elevated $1.1 \mathrm{~m}$ above the ground at the front part of the house (serambi and rumah ibu), whereas the anjung is elevated above the ground about $0.5 \mathrm{~m}$. The rear part of the house was constructed of the brick-and-timber structure directly on the land (dry kitchen, wet kitchen, and rear anjung). The roofing material is using zinc, without a ceiling. Windows of the house comprised full-/half-height timber panel windows with upper ventilation openings above some of the windows, doors, and walls (Figure 1(b)).

In this study, there is a two-stage process of fieldwork. Firstly, it is an observation method, and it is called an on-site physical inventory process. A physical inventory process is required to collect as much information as possible regarding the following details: measurement of the house and compound with the layout, respectively, physical architectural elements, building materials used, and mechanical cooling system use in the house. Secondly is an experimental study (thermal measurement) was conducted in August 2019. August is an expected month to receive the most stable rainfall at an average of 150 to $250 \mathrm{~mm}$ in Negeri Sembilan (Met Malaysia, 2019). Thus, the thermal data would be calm, and the sky is clear with medium cloud cover.

The thermal data was collected in the interior and exterior areas of the house. Data collected point for indoor is $1.1 \mathrm{~m}$ above the floor level (ASHRAE, 2016) and 1.2m from any wall (CLEAR, 2019). Whereas, the measurement for the outdoor area is $5 \mathrm{~m}$ distance from the wall of the house and 1.5m above the ground (Tcollow, 2014). The measure is conducted in 12 hours from 7:00 to 7:30 hours in three days, while no measurement is conducted at night time because of the homeowner's privacy. The data was recorded at 30 minutes intervals and only taken during the overcast sky (partly cloudy) condition, which is a typical type of sky condition in Malaysia. There is no survey conducted in raining and bright sky conditions. The scale of the measurement can be identified by using the environmental parameters (ASHRAE, 2016), air temperature, relative humidity (RH), and wind speed. The measurable scale for temperature is in Celsius, $\mathrm{RH}$ in percentage, and wind speed in meter per second $(\mathrm{m} / \mathrm{s})$. The device used to record the data is Anemometer 4 in 1 . Figure 1 shows the layout plan of the house with an indication of the thermal data point collected. There are 12 points in indoor and outdoor respectively.

The measurable scale for temperature and RH refers to the Canadian index, which is called Humidex (Hassan et al., 2010). Humidex is a parameter intended to express how the combined effects of warm temperatures and humidity are perceived (CCOHS, 2019). The measurable scale (Table 1), shows at the range. No. 2 is considered the best level of performance of temperature factor. Furthermore, in a study by Rahman (1995) also found that the most comfortable indoor temperature in Malaysia ranges between 25.5 and $28^{\circ} \mathrm{C}$ and Misni (2012) define that comfort zone is supposed to be between 20 and $27^{\circ} \mathrm{C}$.
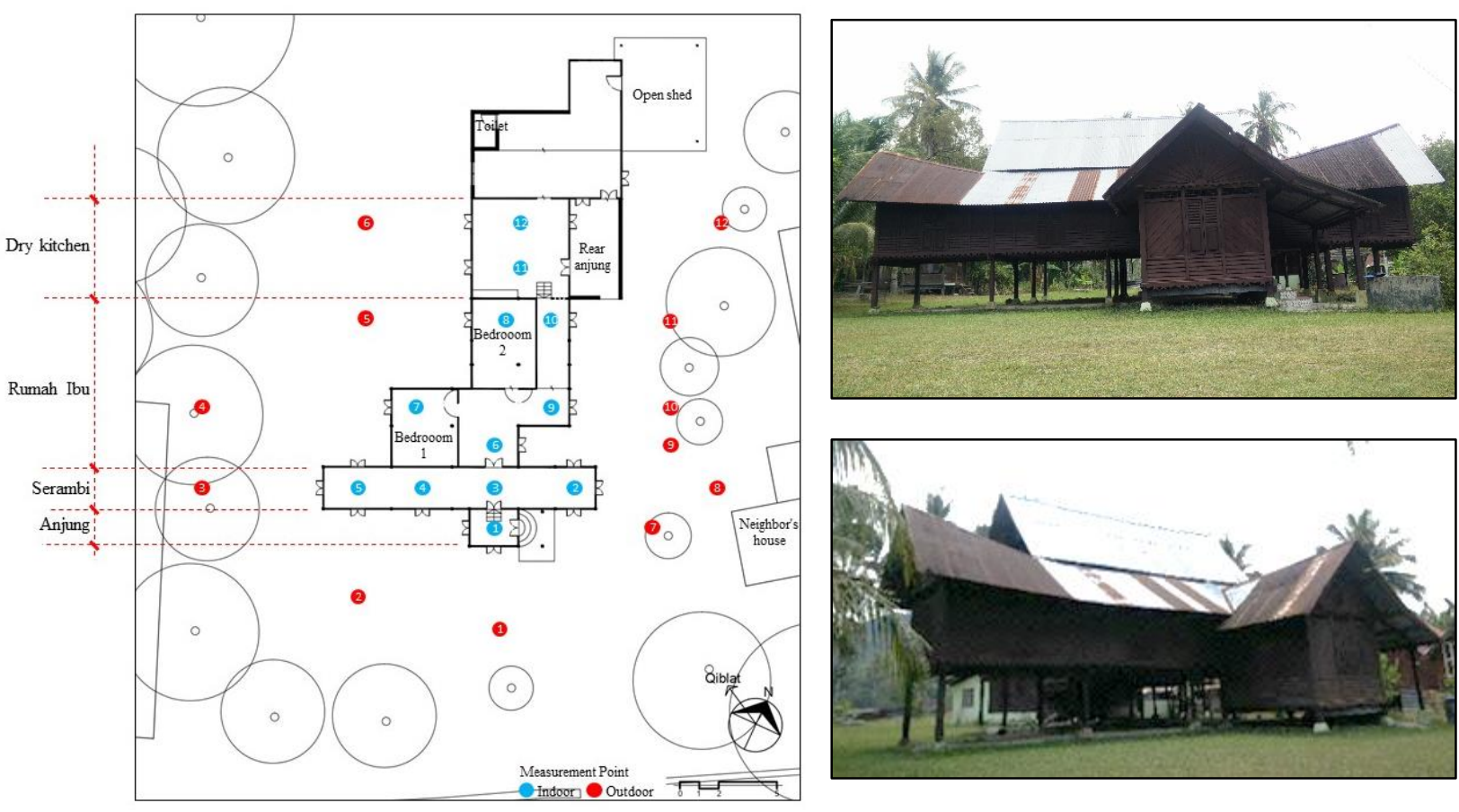

Fig. 1: Plan of the house with the location of measurement point (left), full-height timber panel windows, roofing material (zinc), and exterior view of the case study right) 
Table 1. The measurement scale for temperature

\begin{tabular}{lll}
\hline Scale & Description & Celsius \\
\hline 0 & Cold & Less than 16 \\
1 & Cool & $16-25.5$ \\
2 & Comfort & $25.5-28$ \\
3 & Warm & $28-32$ \\
4 & Hot & $32-40$ \\
5 & Extremely hot & Above 40 \\
\hline \multicolumn{3}{c}{} \\
& (Source: Hassan, 2010)
\end{tabular}

Whereas for $\mathrm{RH}$, the recommended level of indoor relative humidity is in the range of $30-60 \%$ (Table 2). The measurement scale of this factor is divided into three levels of performance, which is shown in Table 2. As for the wind speed measurement scale, the Beaufort Scale was used in this survey. The Beaufort Scale is a system for estimating wind strengths (Croft, 2019), and according to this scale (Table 3), No. 2 and No. 3 is considered as the best level of wind speed performance which at $1.6-5.4 \mathrm{~m} / \mathrm{s}$.

\begin{tabular}{lll}
\multicolumn{2}{c}{ Table 2. The measurement scale for relative humidity $(\mathrm{RH})$} \\
\hline Scale & Description & Percentage $(\%)$ \\
\hline 1 & Low & Below 30 \\
2 & Ideal comfort & $30-60$ \\
3 & High & Above 60 \\
\hline \multicolumn{3}{c}{ (Source: Hassan, 2010) }
\end{tabular}

Table 3. The measurement scale for wind speed

\begin{tabular}{|c|c|c|c|}
\hline Scale & Description & $\mathrm{m} / \mathrm{s}$ & Condition \\
\hline 0 & Calm & $<0.3$ & Calm smoke rises vertically. \\
\hline 1 & Light air & $0.3-1.5$ & Wind motion visible in smoke. \\
\hline 2 & Light breeze & $1.6-3.4$ & Wind felt on exposed skin. Leaves rustle. \\
\hline 3 & Gentle breeze & $3.3-5.4$ & $\begin{array}{l}\text { Leaves and smaller twigs in } \\
\text { constant motion. }\end{array}$ \\
\hline 4 & Moderate breeze & $5.5-7.9$ & $\begin{array}{l}\text { Dust and unattached paper raised. Small } \\
\text { branches begin to move. }\end{array}$ \\
\hline 5 & Fresh breeze & $8.0-10.7$ & $\begin{array}{l}\text { Branches of a moderate size move. Small } \\
\text { trees begin to sway. }\end{array}$ \\
\hline
\end{tabular}

\subsection{Results and discussion}

This part discusses the results of the thermal measurement according to the spatial division of the house; anjung, serambi, rumah ibu, and kitchen. Measurement results on fair days were analyzed. Figure 2 illustrated the air temperature and $\mathrm{RH}$ based on the internal spatial division with the corresponding outdoor thermal conditions.
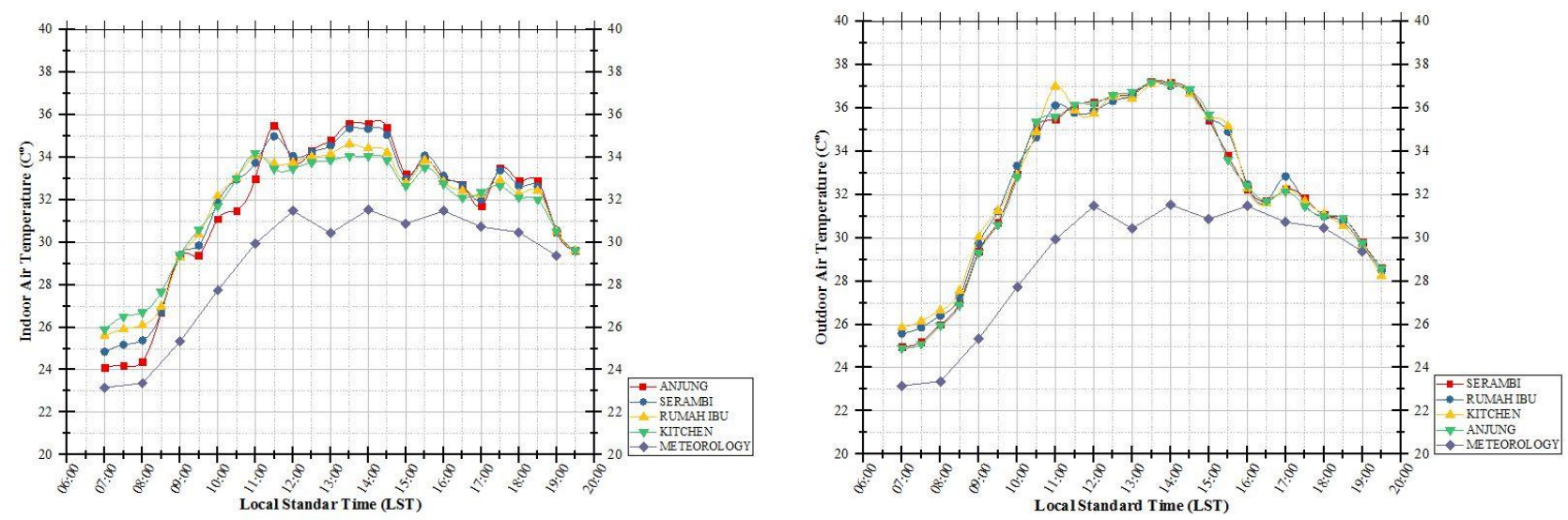

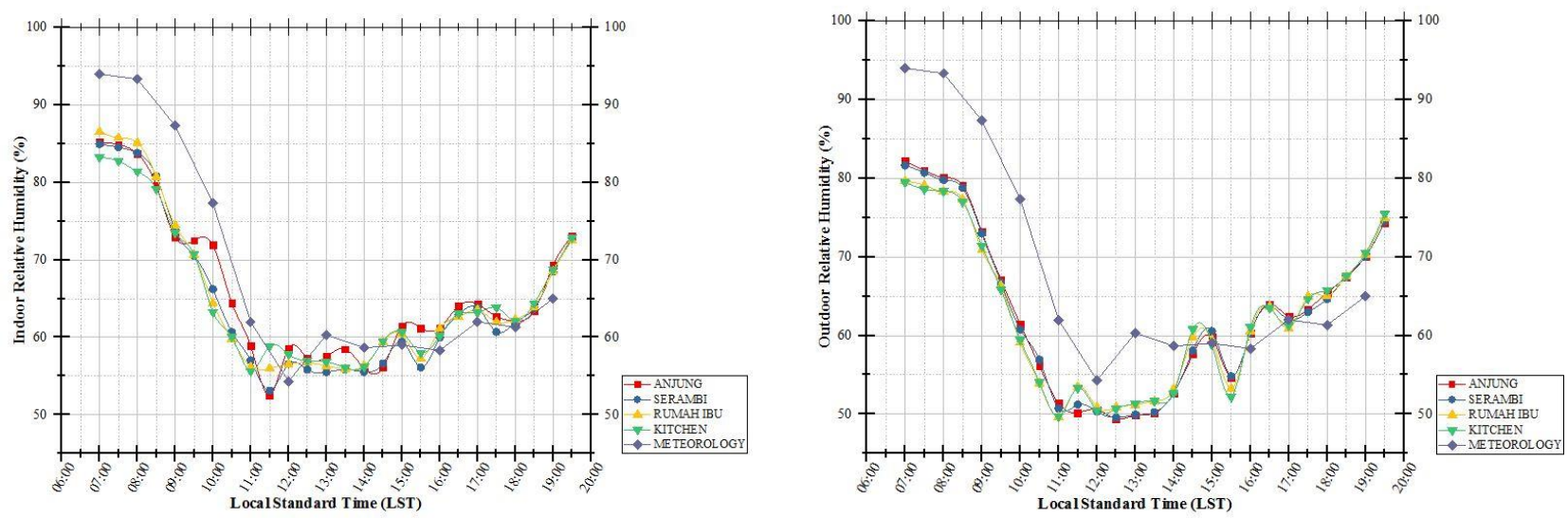

Fig. 2: Measured air temperature and RH based on the internal spatial division with the corresponding outdoor thermal conditions.
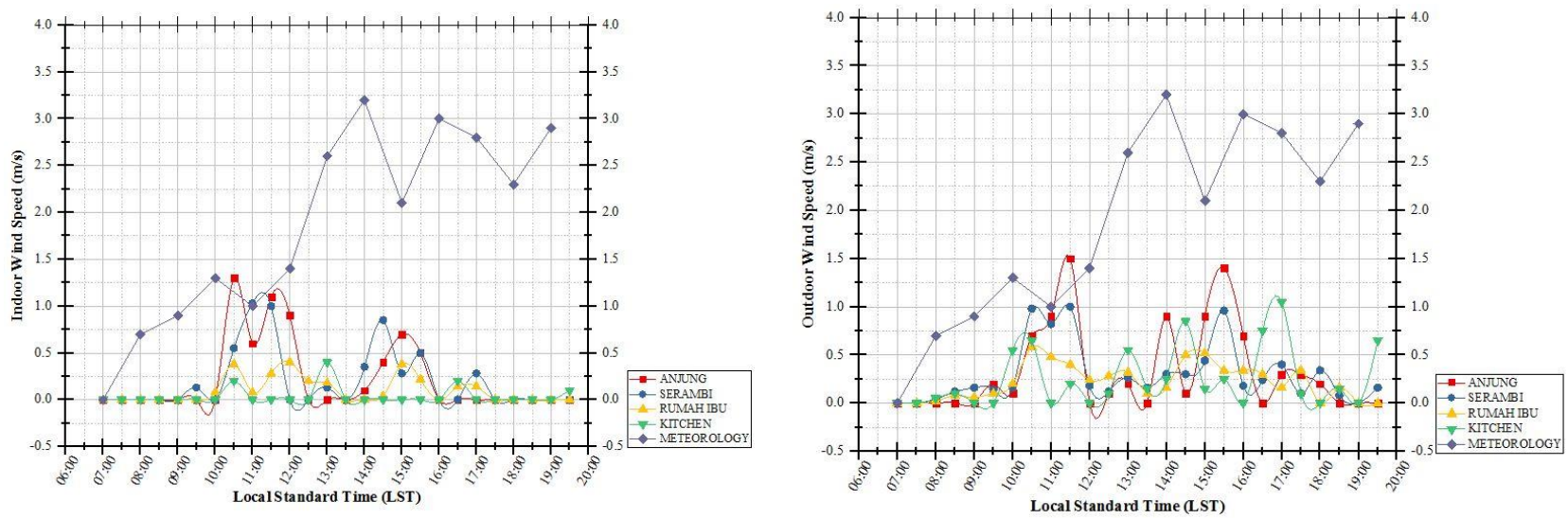

Fig. 3: Measured indoor wind speed of the case study and corresponding with the outdoor conditions.

As shown in Figure 2, there is minimal variation between indoor and outdoor temperatures as well as $\mathrm{RH}$. The indoor thermal data has simultaneous data in responding to outdoor thermal data. Most of the time, the temperature at indoor and outdoor have above $30^{\circ} \mathrm{C}$, which is not under the ranges of ideal comfort level. The house is only under the varieties of comfort level $\left(25.5-28^{\circ} \mathrm{C}\right)$ between $7: 00$ to 8:30 hours except for the anjung. Anjung was only at the comfort level at 8:30 hours, while in the early morning, it was slightly below comfort level, which is at the cold level $\left(16-25.5^{\circ} \mathrm{C}\right)$. Most of the air temperature was ranging between $32-34.5^{\circ} \mathrm{C}$ in indoor and $35-3^{\circ} \mathrm{C}$ in outdoor. Thus, this shows that the air temperature recorded is below the ranges of ideal comfort level, which is in the category of hot $\left(32-40^{\circ} \mathrm{C}\right)$. At 13:30 hours have recorded the maximum indoor and outdoor air temperature. The maximum temperature at anjung and serambi was 35.5 and $37.24^{\circ} \mathrm{C}$, rumah ibu 34.62 and $37.16^{\circ} \mathrm{C}$, and the kitchen are 34.05 and $37.1^{\circ} \mathrm{C}$, respectively. However, at 11.30 hours in anjung has recorded a drastically ascend of temperature compared to the other areas. It indicates that indoor and outdoor air temperatures react to each other. The outdoor was received the sunlight directly as the roof covered the indoor.

The measured relative has shown the gradually changed following the air temperature. The data recorded in Figure 2 shows that when the temperature is high, the lower the relative humidity. There is a minimal variation between indoor and outdoor temperature and relative humidity. The $\mathrm{RH}$ most of the time has recorded above $50-60 \%$, which is under the ranges of ideal comfort level (30-60\%) for both indoor and outdoor from 10:30-16:00 hours, where at this period the air temperature was reached the hot category $\left(32-40^{\circ} \mathrm{C}\right)$. The highest measured of $\mathrm{RH}$ in outdoor and indoor areas was at 7.00 hours, which is varies between $80-84 \%$ (Scale 3-high). The surrounding and indoor of the house happened to have a high reading of $\mathrm{RH}$ from 7:00-10:30 hours because of the trees and lawn compound area doing the evapotranspiration process.

Anjung, serambi, and kitchen areas have recorded the most wind flow into the interior (Figure 3). Anjung has measured the highest wind flow, which is $1.5 \mathrm{~m} / \mathrm{s}$ at 11:30 hours and followed by $1.4 \mathrm{~m} / \mathrm{s}$ at 15:30 hours under scale one1 light air. Whereas, rumah ibu and kitchen have achieved wind speed measured slightly under the category light wind flow in ranged $0.1-0.35 \mathrm{~m} / \mathrm{s}$ as well as serambi. It shows that the part or division of the house has different wind performance. Anjung and serambi are easily allowed the wind flow into the home because there are plenty of full-height operable windows, and it constructs on stilt with $0.5 \mathrm{~m}$ and more than $1 \mathrm{~m}$, respectively. Besides, the location at the front part of the house, where the outdoor compound is free from any wall or trees blocking the air flows. The air temperature measured indoor and outdoor of the house have descended $\left(33-\right.$ to $\left.28^{\circ} \mathrm{C}\right)$ start from $18: 00-19: 30$ hours, where the sun is going ready to set. However, it was still under the warm category $\left(28-32^{\circ} \mathrm{C}\right)$. These data recorded have to correspond towards the measured relative humidity where the air humidity has an increase (60-75\%) under the air temperature decrease. Also, the outdoor wind flow has barely recorded $0 \mathrm{~m} / \mathrm{s}$ at that time being with ranged between $0.2-0.4 \mathrm{~m} / \mathrm{s}$, which is under the light air category. 


\subsection{Conclusion and recommendation}

According to the indoor air temperature, $\mathrm{RH}$ and wind speed data recorded can conclude that the size of floor areas, numbers of the windows or openings with upper ventilation lattice, floor, roof height, and lawn compound area influence the thermal performance of a house. Each division of the house produced different thermal performance. As per the result recorded for wind speed, the serambi has recorded there was wind flow into the home because of the raised floor can catch winds of higher velocity even though it is located between anjung and rumah ibu. Moreover, it is also supported by the full-height operable windows with upper ventilation lattice, which allow cross-ventilation at body level (Figure 4). Besides, the indoor air temperature has measured small variations between the spatial divisions. Even though rumah ibu is located at the middle part of the house and has measured the wind flow in Scale 1 which is light air $(0.3-1.5 \mathrm{~m} / \mathrm{s})$, it is still and remained recorded the lowest air temperature between anjung, serambi, and kitchen. It is because rumah ibu has the highest pitch of roof with $5.6 \mathrm{~m}$ than the other spatial division. The ventilated gable end on the roof helps to cool the house and executed the hot air through the roof joint. Furthermore, the height of the ceiling allows the stack effect in rumah ibu. Whereas, the material used to construct a house also plays an important role. This case study is used zinc as the material for the roof. The zinc materials have made the interior of the house became warmer and hot. Thus, this is creating discomfort in indoor performance.

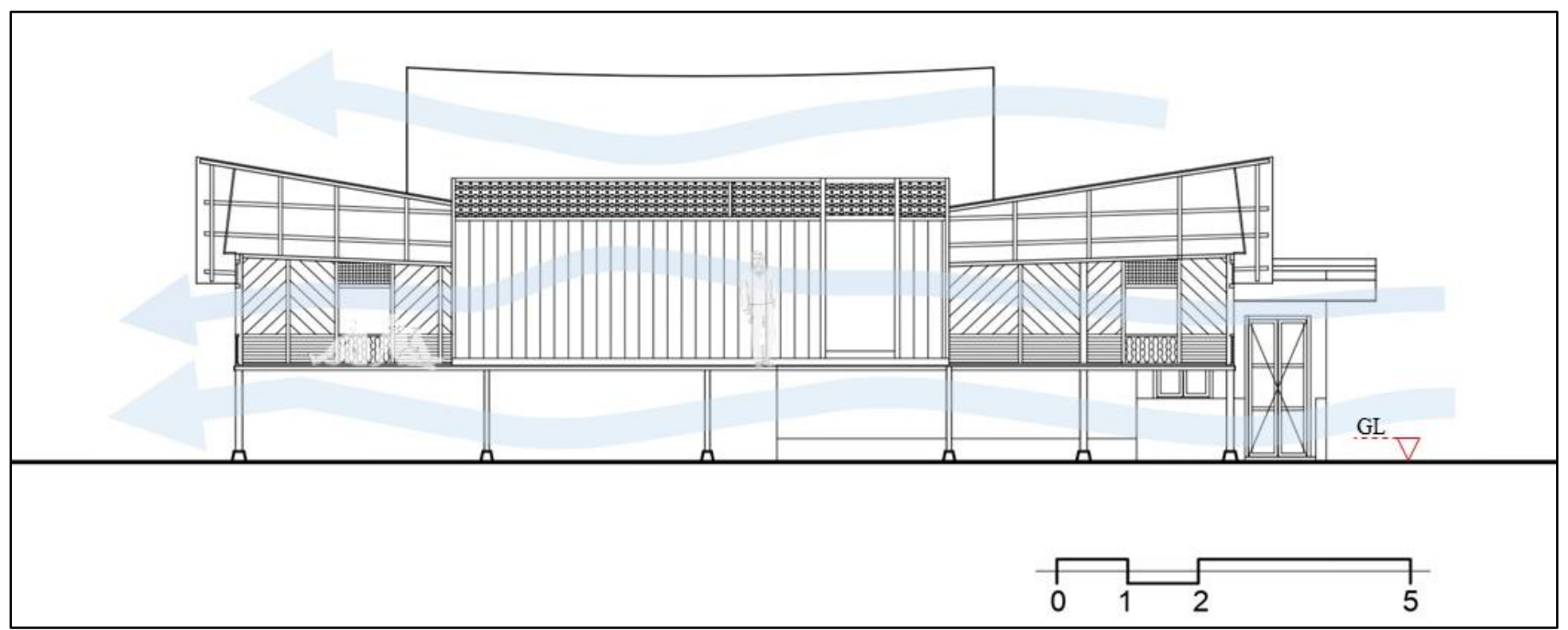

In conclusion, it shows that a study and rediscover our indigenous solutions are is highly encouraged to properly fine-tuned to meet our own socio-economic, cultural, and environmental conditions, especially in construction technology for modern residential architecture. It is lessons can also be drawn from the climatic design of the traditional Malay house for housing in the contemporary context. Although the use of appropriate building materials like wood and thatch may not be suitable for high-density living in the urban areas, house-made up of wood and lightweight construction can be promoted in the suburban areas where densities are not so high. The appropriate solar-radiation and glare controls in the Malay house are other samples of effective climatic design which are applicable to adapt in modem housing. The orientation of modern homes must carefully design to minimize solar heat gain to the building. The essential element in controlling solar radiation is the roof should construct from low-thermal-capacity materials. The maximization of the passive design system which exhibited in the traditional Malay house should adapt to modern house design. Thus, to improve housing quality, the problem of housing scarcity must also be overcome and indirectly can promote sustainable practice.

\section{References}

Amad, A. M., Sujud, A. e., \& Hasan, H. Z. (2007). Proxemics and its Relationship with Malay Architecture.

ASHRAE. (2016). Standard 55-2013 User's Manual: ANSI/ASHRAE Standard 55-2013, Thermal Environmental Conditions For Human Occupancy. Atlanta, GA: ASHRAE Research.

Cartalis, C., Synodinou, A., Proedrou, M., Tsangrassoulis, A., \& Santamouris, M. (2001). Modifications in energy demand in urban areas as a result of climate changes: An assessment for the southeast Mediterranean region. Energy Conversion and Management, 42, 1647-1656. doi:10.1016/S0196-8904(00)00156-4

CCOHS, C. C. f. O. H. S. (2019). Humidex Rating and Work. Retrieved from https://www.ccohs.ca/oshanswers/phys_agents/humidex.html
CLEAR.
(2019).
Measuring
Conditions in the Room.
Retrieved from
https://www.new-

learn.info/packages/clear/thermal/people/surveying/measurements/measuringconditions.html

Cockrem, T. (2003). Romancing The Traditional Malaysian Home. Retrieved from http://thingsasian.com/story/romancing-traditional-malaysian-home

Croft, J. (2019). The Beaufort Scale. Retrieved from https://www.anbg.gov.au/jrc/kayak/beaufort.html 
Hanafi, Z. (1994). Housing design in relation to environmental comfort - a comparison of the traditional Malay house and modern housing. Building Research \& Information, 22(1), 21-33. doi:10.1080/09613219408727341

Hassan, A. S., \& Ramli, M. (2010). Natural Ventilation of Indoor Air Temperature: A Case Study of the Traditional Malay House in Penang. American Journal of Engineering and Applied Sciences, 3(3), 521-528. doi:10.3844/ajeassp.2010.521.528

Hosseini, E., Mursib, G., Nafida, R., \& Shahedi, B. (2014). Malay Vernacular Architecture: Mirror Of The Past, Lessons For The Future. Paper presented at the The Proceedings of 8th SEATUC Symposium

Jamaludin, N., Mohammed, N. I., Khamidi, M. F., \& Wahab, S. N. A. (2015). Thermal Comfort of Residential Building in Malaysia at Different Micro-climates. Procedia Social and Behavioral Sciences, 170,613-623. doi:10.1016/j.sbspro.2015.01.063

Kamal, K. S., Wahab, L. A., \& Ahmad, A. C. (2004, 10-12 November 2004). Climatic design of the traditional Malay house to meet the requirements of modern living. Paper presented at the The 38th International Conference of Architectural Science Association ANZAScA, Launceston, Tasmania.

Kubota, T., \& Toe, D. H. C. (2012). RE-EVALUATING PASSIVE COOLING TECHNIQUES OF TRADITIONAL MALAY HOUSES IN MALAYSIA. Paper presented at the iNTA 2012 (4th International Network for Tropical Architecture, National University of Singapore.

Lundgren, K., \& Kjellstrom, T. (2013). Sustainability Challenges from Climate Change and Air Conditioning Use in Urban Areas. Sustainability, 5(7), 3116-3128. doi:10.3390/su5073116

MetMalaysia, M. M. D. (2019). TINJAUAN CUACA BAGI TEMPOH MEI HINGGA OKTOBER 2019. Retrieved from http://www.met.gov.my/data/climate/tinjauancuacajangkapanjang.pdf

Misni, A. (2017). Residential Space-Cooling Energy Use. Asian Journal of Quality of Life, 2(8), 45-53. doi:https://doi.org/10.21834/ajqol.v2i8.69

Misni, A. (2012). THE EFFECTS OF SURROUNDING VEGETATION, BUILDING CONSTRUCTION AND HUMAN FACTORS ON THE THERMAL PERFORMANCE OF HOUSING IN A TROPICAL ENVIRONMENT. Wellington: Victoria University of Wellington

Naseer, M. A. (2013). Energy Efficient Building Design: Revisiting Traditional Architecture. Paper presented at the The Asian Conference on Sustainability, Energy and the Environment 2013, Osaka, Japan.

Rahman, A. M. A. (1995). Housing Design in Relation to Environmental Comfort. Building Research \& Information, 23(1), 49-54. doi:10.1080/09613219508727423

Ramakreshnan, L., et al. (2018). A critical review of Urban Heat Island phenomenon in the context of Greater Kuala Lumpur, Malaysia. Sustainable Cities and Society 39, 99-113. doi:10.1016/j.scs.2018.02.005

Sahabuddin, M. F. M. (2012). Chapter 2: Malaysian Vernacular Architecture and Its Relationship to Climate. (Masters of Science (Advanced Sustainable Design)), The University of Edinburgh, The University from https://www.academia.edu/2377416/Chapter_2_Malaysian_Vernacular_Architecture_and_Its_Relationship_to_Climate (s1131077)

Sahabuddin, M. F. M., \& Gonzalez-Longo, C. (2015). Traditional Values and Their Adaptation in Social Housing Design - Towards a New Typology and Establishment of 'Airhouse' Standard in Malaysia. Venice Italy.

Talib, R. B., \& Sulieman, M. Z. (2012). Classification of factors contributing to sustainable issues on selected Traditional Malay Houses and Bio-climatic buildings (pp. 113): Universiti Sains Malaysia.

Tcollow. (2014). How to Measure Temperature Correctly. Retrieved from https://www.weatherworksinc.com/temperature-measurement

Toe, D. H. C., \& Kubota, T. (2013). FIELD MEASUREMENT ON THERMAL COMFORT IN TRADITIONAL MALAY HOUSES AIJ J. Technol. Des, 19(41), 219-224.

Yuan, L. J. (1988). The traditional Malay house The Malay House: Rediscovering Malaysia's Indigenous Shelter System (pp. 73-97): Institut Masyarakat.

Zin, M. H. M., Ibrahim, N. L. N., \& M. F. M. Zain, M. J. (2012). The Social and Environmental Roles of Verandah in Tropical Houses. International Journal of Architectural and Environmental Engineering, 6(8), 2213-2215. 